\title{
Feeding Ecology of Sloth Bears in Chitwan National Park, Nepal
}

\author{
Sandip Khanal ${ }^{1} \&$ Tej B. Thapa ${ }^{2}$ \\ Central Department of Zoology, Tribhuvan University, Kathmandu, Nepal \\ E-mail: 1small_sandy2007@yahoo.com \& 2tbthapa@cdztu.edu.np
}

\begin{abstract}
Food habits of a species influences habitat use, ranging pattern and behavior. Seasonal diet composition of Sloth bear (Melursus ursinus) in the Chitwan National Park, Nepal was determined from 143 scats. Through macroscopic and microscopic analysis of scats; six types of plants, termites, ants, honey bees, wax, as well as mammalian hairs were identified. Although variation was observed, there was no significant difference in the diet composition in two different seasons. Overall, insects dominated the composition, occurring in $100 \%$ of the scats followed by the plants $(39.16 \%)$ and mammalian hair (3.49\%). Termites and ants were the major and stable dietary components. Termites (90\%), Red ants $(65 \%)$ and Aegle marmelos (35\%) were important food for Sloth bear in summer season but the utilization of plants was very low. During winter, insects were heavily utilized by the bear. The utilization of termites (93.97\%) and Ziziphus sp. (14.45\%) was higher in comparison with summer season. Utilization of fruits in summer was negligible. By and large, on percent dry weight basis, insects (78.98\%) dominated Sloth bear diet, followed by plants $(20.99 \%)$ and mammalian hairs $(0.04 \%)$.
\end{abstract}

Key words: Sloth bear, feeding, scat, insects, termites, diet composition

\section{INTRODUCTION}

Understanding food habits and diet composition is important to assess distribution and habitat use of the bears (MacHutchon \& Wellwood, 2003). Most of the bears are opportunistic omnivores. All the bears, except Polar bear (Ursus maritimus) have been documented to feed on insects, especially ants (Joshi et al. 1997). However, Sloth bear is only the ursid having mymercophagus adaptation to feed on insects, especially termites and ants (Laurie \& Seidensticker, 1977; Joshi et al. 1997). The diets of Sloth bear vary seasonally and geographically across their range (Laurie \& Seidensticker, 1977; Gokula et al. 1995; Baskaran et al. 1997; Joshi et al. 1997; Bargali et al. 2004). Sloth bear is only the species that entirely depend on social insects for its protein requirements (Yoganand $e t$ al. 2005). Various factors such as abundances, dispersion and bite size, availability and taste of fruits of plants and colony size and colony biomass of insect determine diet selection pattern of the Sloth bears (Yoganand et al. 2005).

Previous research revealed that insects are the main food components of bear all year round (Laurie \& Seidensticker, 1977; Shrestha, 1993; Joshi et al. 1997), but fruits are major portion of diet during fruiting season (April- May) in Chitwan, Southern India (Gokula et al. 1995) and central India (Bargali et al. 2004). However, fruits comprised a major portion of diet in South India (Baskaran et al. 1997), in Panna National Park (Yoganand et al. 2005), in Vijaynagar North Gujarat (Mewada \&
Dharaiya, 2010). They occasionally feed on animal carcasses when food sources are limited (Shrestha, 1993; Baskaran et al. 1997; Bargali et al. 2004; Mewada \& Dharaiya, 2010; Ramakrishnan \& Deepalakshmi, 2012). The objective of this study was to determine seasonal diet composition of Sloth bear in Chitwan National Park (CNP) using macroscopic and microscopic examination of scats remain.

\section{MATERIALS AND METHODS}

\section{Study area}

The study was carried out in Chitwan National Park (CNP) situated between $27^{0} 34^{\prime}$ to $27^{\circ} 68^{\prime}$ North and $83^{\circ} 87^{\prime}$ to $83^{\circ} 74^{\prime}$ East, covering an area of $932 \mathrm{~km}^{2}$ (Fig. 1). The Park has two Siwalik ranges, namely Churia and the Someswore, which rises about $150 \mathrm{~m}$ to over $800 \mathrm{~m}$. Rapti and Reu flow through the park and ultimately join the Narayani, in between there are several depressions forming lakes and marshes with perennial water resources. In Chitwan, mean annual temperature is $17.6^{\circ} \mathrm{c}$, winter temperature falls almost to freezing point, whereas, from March to June temperature can reach as high as $43^{\circ} \mathrm{c}$. About $90 \%$ of rainfall occurs from May to September with annual rainfall of $1520 \mathrm{~mm}$. In addition to the Sloth bear, other large mammals in this area includes Rhinoceros unicornis, Elephus maximus, Bos Gaurus, Panthera tigris, Tetracerus quadricornis etc. Important floras in the park are Shorea robusta, Pinus roxburghii, Bombax Ceiba, Delbergia sisso, Ficus cunia etc. 


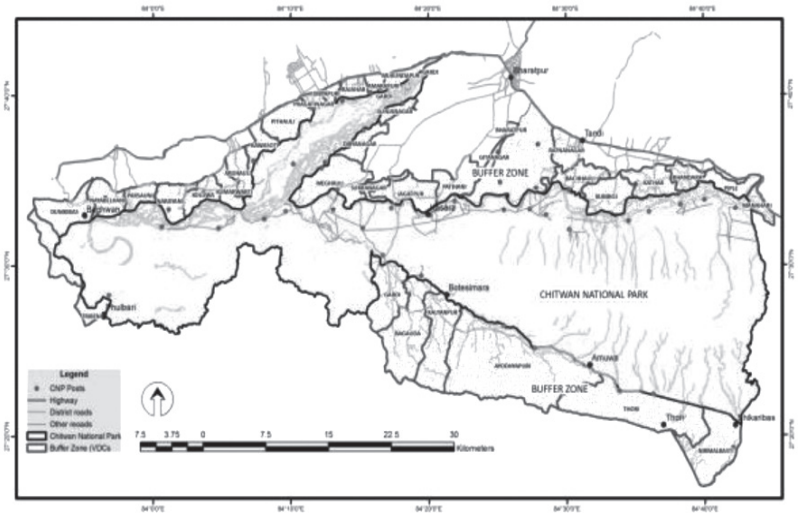

Fig. 1. Map of Chitwan National Park and Buffer Zone.

\section{Scat collection}

For the scat collection entire study area was divided into 70 grids with $4 \times 4 \mathrm{Km}^{2}$ (Fig. 2) and scats were collected during April-May 2012 and February 2013 in 32 (45\%) of the selected grids as well as along the trail and dirt roads in the CNP and BZ. Scats whenever encountered were dried in the sun if necessary and stored in polythene bags with proper labeling. These scats were then taken to the laboratory of Central Department of Zoology (CDZ), Tribhuvan University for analysis.

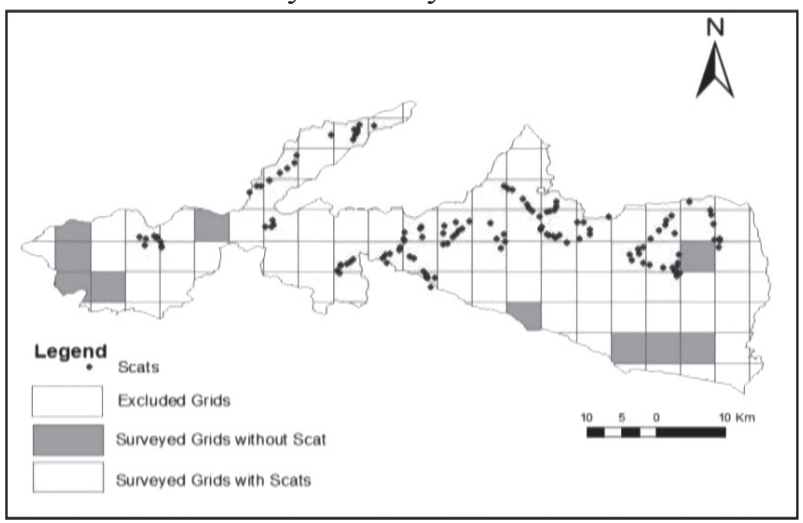

Fig. 2. Map showing surveyed, scat collected and excluded grids in CNP.

\section{Scat analysis}

Scat analysis were done following the method used by Gokula et al. (1995), Baskaran et al. (1997), Joshi et al. (1997), Bargali et al. (2004). The scat samples were soaked in water for about 15 hours and washed in running water to remove mud and other debris through the sieves of 0.7 and $0.4 \mathrm{~mm}$ mesh size. Remaining portion of each scat was oven dried at $60^{\circ} \mathrm{C}$ for about 24 hours, weighed separately and only 4 gm from each sample was used for further analysis. Sample of dried material was sprinkled in a thin layer of non overlapping particles on a paper marked with 16 square boxes of $4 \mathrm{~cm}$ length and materials of 2 boxes were selected randomly. Scat samples were analyzed manually by separating components. A dissecting microscope (40X) was used to identify food items when needed. All inseparable, unidentified crushed matters including parts of insects and fruits were discarded. Fruits were identified by comparing the seeds of fruits collected during field visit. Head parts of the insects were used for their identification. Seeds and insect part thus collected were weighted separately for analyzing the dry weight composition of food items. Remains of hairs and wax were considered as sources of indication of feeding carrion and honey. Food items were broadly grouped into "Insects", "Plants" and "Mammalian Hair".

Scat composition was quantified by both frequency of occurrence and percent dry weight (Gokula et al. 1995, Baskaran et al. 1997, Bargali et al. 2004). Kruskal-Wallis Rank Sum test was used to test the significant difference in diet composition of bear between seasons using program R (R Console version 2.15.2).

\section{RESULTS}

\section{Overall diet composition}

Altogether, 143 scats including 60 from summer (AprilMay) and 83 from winter season (February) were collected, and analyzed. Thirteen different types of food items occurred in total scats; six taxa of plants, five taxa of insects as well as wax and mammalian hair (Table 1).

Table 1. Over all frequency of occurrence of food items in scats of Sloth bears in Chitwan National Park

\begin{tabular}{|c|c|c|c|c|}
\hline \multirow{2}{*}{$\begin{array}{c}\text { Food } \\
\text { Categories }\end{array}$} & \multirow{2}{*}{$\begin{array}{l}\text { Food } \\
\text { items }\end{array}$} & $\begin{array}{c}\text { Summer } \\
(n=60)\end{array}$ & $\begin{array}{l}\text { Winter } \\
(n=83)\end{array}$ & Overall \\
\hline & & $\begin{array}{c}\% \\
\text { occurrence }\end{array}$ & $\begin{array}{c}\% \\
\text { occurrence }\end{array}$ & $\begin{array}{c}\% \\
\text { occurrence }\end{array}$ \\
\hline \multirow{6}{*}{ Insects } & Termites & 90 & 93.97 & 92.3 \\
\hline & Black ants & 61.66 & 57.83 & 59.44 \\
\hline & Red ants & 65 & 34.93 & 47.55 \\
\hline & Beetle & 21.66 & 4.81 & 10.48 \\
\hline & Honey bee & 21.66 & 7.22 & 13.28 \\
\hline & Wax & 3.33 & 0 & 1.39 \\
\hline $\begin{array}{l}\text { Mammalian } \\
\text { Hair }\end{array}$ & Hair & 5 & 2.4 & 3.49 \\
\hline \multirow{6}{*}{ Plants } & $\begin{array}{l}\text { Aegle } \\
\text { marmelos }\end{array}$ & 35 & 0 & 14.68 \\
\hline & Ziziphus spp. & 3.33 & 14.45 & 9.79 \\
\hline & Bridelia retusa & 10 & 0 & 4.19 \\
\hline & $\begin{array}{l}\text { Ficus } \\
\text { semicaudatum }\end{array}$ & 21.66 & 1.2 & 9.79 \\
\hline & Cassia fistula & 0 & 7.22 & 4.19 \\
\hline & $\begin{array}{l}\text { Ficus } \\
\text { benghalensis }\end{array}$ & 0 & 2.4 & 1.39 \\
\hline
\end{tabular}


Insects dominated the composition, occurring in $100 \%$ of the scats followed by the plants $(39.16 \%)$ and mammalian hair $(3.49 \%)$. Among the food items, termites $(92.30 \%)$ occurred in scats most often. Of the plant species found in the scats, Aegle marmelos (14.68\%) was found most frequently. On the dry weight basis also, insect (78.98\%) contributed highest and the rest by plants and mammalian hair (Table 2). Termite was highest ranking insect item on dry weight basis and Ziziphus sp. ranged highest among the plants, followed by Aegle marmelos (4.13\%). Mammalian hair contributed least, having only $0.04 \%$ dry weight composition.

Table 2. Percent dry weight composition of food items in the scats of Sloth Bears by season in Chitwan National Park.

\begin{tabular}{|l|l|c|c|c|}
\hline \multirow{4}{*}{$\begin{array}{l}\text { Food } \\
\text { Categories }\end{array}$} & Food Items & $\begin{array}{c}\text { Summer } \\
\text { \% dry } \\
\text { weight }\end{array}$ & $\begin{array}{c}\text { Winter } \\
\text { weight }\end{array}$ & $\begin{array}{c}\text { Total } \\
\text { Total dry } \\
\text { weight \% }\end{array}$ \\
\hline \multirow{4}{*}{ Insects } & Termites & 55.52 & 66.48 & 62.7 \\
\cline { 2 - 5 } & Black ants & 6.07 & 10.47 & 8.95 \\
\cline { 2 - 5 } & Red ants & 7.47 & 2.99 & 4.53 \\
\cline { 2 - 5 } & Beetle & 2.66 & 0.56 & 1.27 \\
\cline { 2 - 5 } & Honey Bee & 2.05 & 0.56 & 1.07 \\
\cline { 2 - 5 } Hair & Wax & 1.14 & 0 & 0.39 \\
\hline \multirow{5}{*}{ Plants } & Hair & 0.02 & 0.04 & 0.04 \\
\cline { 2 - 5 } & $\begin{array}{l}\text { Aegle } \\
\text { marmelos }\end{array}$ & 12 & 0 & 4.13 \\
\cline { 2 - 5 } & Ziziphus spp. & 3.35 & 13.65 & 10.1 \\
\cline { 2 - 5 } & $\begin{array}{l}\text { Bridelia } \\
\text { retusa }\end{array}$ & 6.54 & 0 & 2.25 \\
\cline { 2 - 5 } & $\begin{array}{l}\text { Ficus } \\
\text { semicaudatum }\end{array}$ & 3.12 & 0.84 & 1.62 \\
\cline { 2 - 5 } & Cassia fistula & 0 & 0.58 & 0.38 \\
\cline { 2 - 5 } & $\begin{array}{l}\text { Ficus } \\
\text { benghalensis }\end{array}$ & 0 & 3.77 & 2.47 \\
\hline \multirow{5}{*}{ Senalian } & & & \\
\hline
\end{tabular}

\section{Seasonal diets}

In the summer season, insects were most heavily utilized food items, dominating in term of both; frequency of occurrence and percent dry weight. Termites occurred more frequently $(90 \%)$ in the scat samples than Red ants $(65 \%)$ and Black ants (61.66\%). Plant species occurred in $63.33 \%$ of scats in the summer season. Aegle marmelos $(35 \%)$ occurred more frequently among the plants, followed by Ficus semicaudatum (21.67\%). Expressed in term of dry weight, termite $(62.70 \%)$ was highest among insects and Aegle marmelos (12\%) among the plants (Table 2).

In the winter season also, insects were heavily utilized, occurring in $100 \%$ of the scats. Here, also termites $(93.97 \%)$ occurred more frequently followed by Black ants $(57.83 \%)$ and Red ants (34.93\%). Plants occurred in only $21.68 \%$ of the scats. Ziziphus sp. (14.45\%) was more frequent among the plants followed by the Cassia fistula (7.22\%). In term of percent dry weight, insect contributed $81.03 \%$ and remaining by plants, least by mammalian hair. Ziziphus sp. (13.65\%) contributed highest among the plants.

\section{Seasonal variation of diet composition}
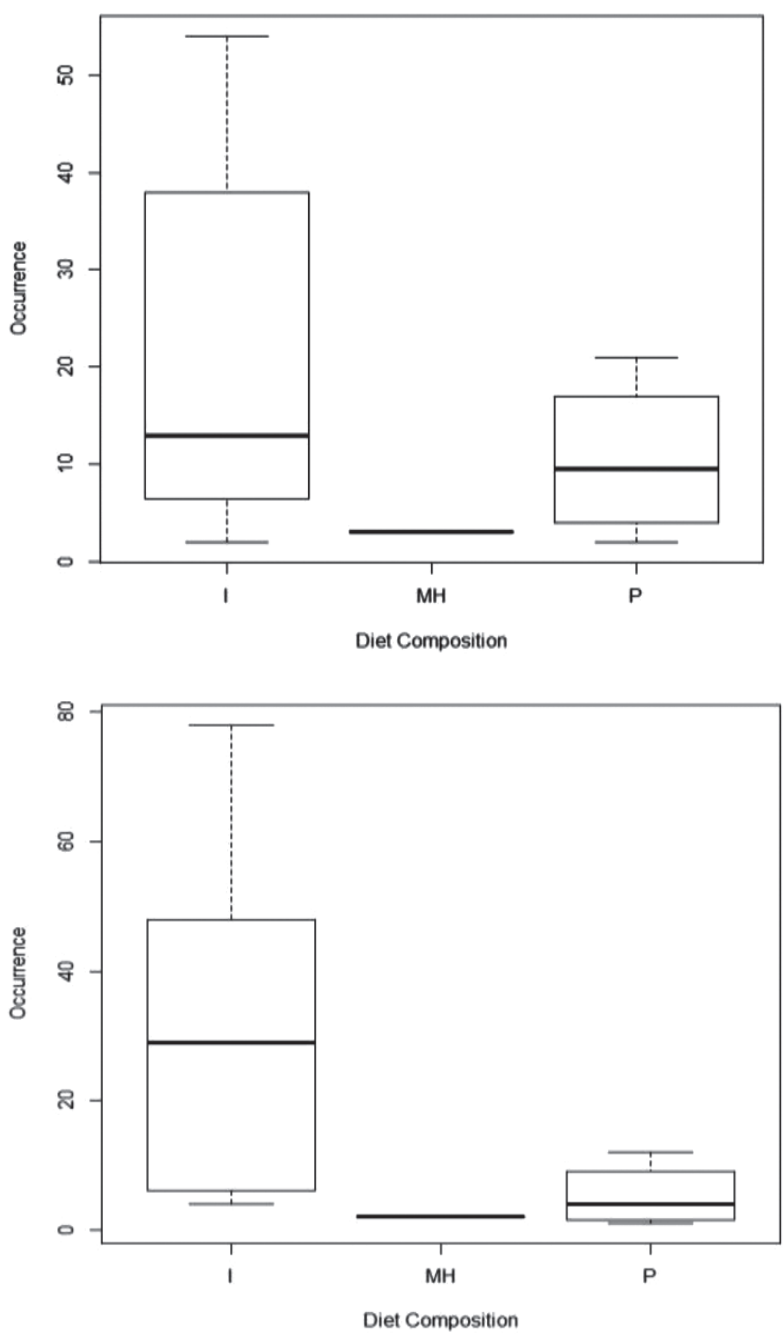

Fig. 3. Boxplots showing diet composition of Sloth bear in summer (1a) and winter season (1b) $(\mathrm{I}=$ insects, $\mathrm{MH}=$ Mammalian hair, $\mathrm{P}=$ plants). The dark line in the box plot represents the median or mid value and its arm represents the quartile value of number of diet composition.

Kruskal Wallis test revealed that there was no significant difference $(p>0.05)$ in the composition of diet of Sloth bear between two seasons $\left(\mathrm{X}^{2}=0.8586, \mathrm{df}=1, \mathrm{p}=0.3541\right.$, 
$\alpha=0.05$ ). Both seasons had more or less same composition of diet. Insects were the major diet followed by plants and the least as mammalian hair (Figs. 3a \& 3b).

\section{Adequacy of sample size}

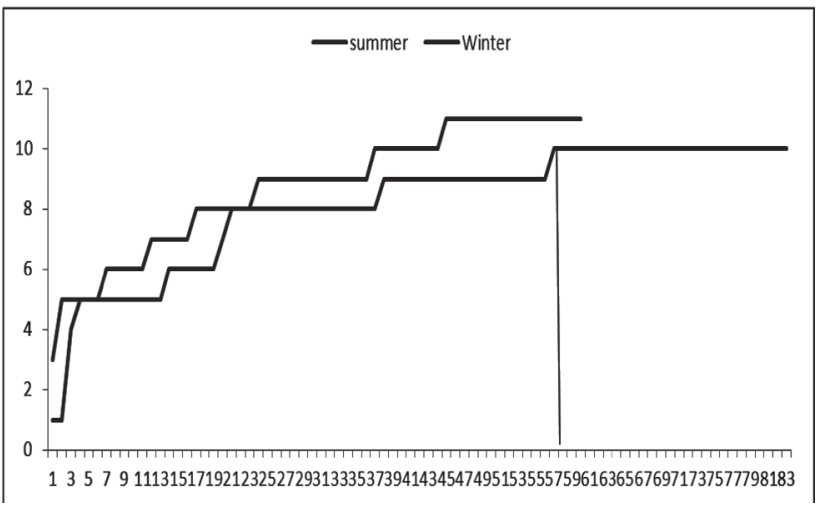

Fig. 4. Relationship between number of taxa occurred and number of scats analyzed in summer and winter season.

All the food items in the Sloth Bears diet were identified after analysis of 45 scat samples in summer season and 57 samples in winter season (Fig. 4).

\section{DISCUSSION}

Diets of Sloth bear have been analyzed in Chitwan by identifying remains of undigested food remains in the scat samples. Scat analysis is widely used method for diet analysis of Sloth bear (Laurie \& Seidensticker, 1977; Gokula et al. 1995; Joshi et al. 1997) as it is a non invasive technique.

Sloth bears are opportunistic omnivores and their diet vary seasonally and geographically (Joshi et al. 1997). As in other studies, Sloth bear in CNP consumed insects, plants and mammalian carcasses, with variation probably related to food availability in different season (Laurie \& Seidensticker, 1977; Gokula et al. 1995, Baskaran et al. 1997; Joshi et al. 1997; Bargali et al. 2004). In CNP, Sloth bear overall consumed 13 different taxa including six plants, five insects as well as wax and mammalian hair (Table 1). The diet diversity of Sloth bear identified in this study was less than that detected by previous researcher in CNP (Laurie \& Seidensticker 1977, Shrestha 1993; Joshi et al. 1997). Low diet diversity of this study is probably related to the shorter duration of scat sampling in this study. Insects were the most common diets occurring in $100 \%$ scats. Similar results were reported by Sultan et al. (2012) from dry deciduous forests of Darrah Wildlife Sanctuary, India. However, Laurie and Seidensticker (1977) reported insects only in 52\% of scats. This large difference is probably related with change in the habitat conditions of CNP between these studies as alluvial grasslands of the park was previously inhabited by the people, alluvial grassland are preferred by Sloth bears because of high density of termites (Joshi et al. 1995). Termites were the most important stable food items followed by ants. Proportion of insects (i.e. almost entirely termites and ants) in Sloth bear's diets was relatively higher in this study than previous studies, probably insects population in Chitwan are higher than others. The soft soils in Chitwan may be favourable for those insect taxas. The higher representation of insects matter in Sloth bear diet is probably related to easier digestibility and higher nutritional value of insects. The Sloth bears entirely depend on social insects (termites, ants) for its protein requirements (Yoganand et al. 2005).

The proportion of plant material (39.16\%) occurred in the diets of the Sloth bear is higher than that reported by Gokula et al. (1995) in Mundanthurai Plateau, Tamil Nadu, India. Gokula et al. (1995), collected scats during December - March, which is non-fruiting. Monsoon is the main fruiting season for most of the plants but scats were not collected during his season due to heavy rain, water logging in much of the lowland areas and flooding of many rivers. This limitation probably related to the less number of plant taxa than previous studies (Laurie \& Seidensticker 1977, Shrestha 1993; Joshi et al. 1997). .

Percentage frequency of mammalian hairs was lowest $(3.49 \%)$ in the diets. Presence of mammalian hairs probably indicates the carrion feeding behaviour of Sloth bear. The hairs and bones in scat were also reported by other researchers (Shrestha, 1993; Bargali et al. 2004), Sreekumar \& Balakrishnan (2012) and in addition hairs and bones bird feathers were also reported by Baskaran et al. (1997) and Mewada \& Dharaiya (2010). All these indicate Sloth bear feeding diverse food items.

During the summer season, Sloth bear preferred insect diet. Beetle and Honey bee were the insects which unlike others occurred more in summer season. Relative importance of Honey bee found in the bears scats during summer season may be due to seasonal flowering of some plants. During winter season, utilization of insect matter was higher, hard soil during the summer season probably deterred bears from digging for termites and ants (Joshi et al. 1997; Bargali et al. 2004; Sukhadiya et al. 2012; Ramakrishnan \& Deepalakshmi, 2012). Among the plants, Ziziphus sp. (14.45\%) in winter and Aegle marmelos $(35 \%)$ in summer was recorded higher probably as it was the fruiting season for both the species. They also contributed higher in dry weight basis it may be due to their larger seed size. Plants showed lesser contribution in diet during winter season than in summer season. The relative importance of the plant matter in bear diets during summer season may be due to seasonal flowering and fruiting. 
In CNP all viz; insects, plants and mammalian hair contributed to the diets of the Sloth bear. Although, variation occurred in dietary composition between two seasons (summer and winter), there was no significant difference $\left(X^{2}=0.8586, d f=1, p=0.3541, \alpha=0.05\right)$ in the diet composition of Sloth Bears. Termites play important roles by providing a constant supply of food throughout the year. This is particularly important during winter when bear finds it easy to dig for termites and ants and there is less number of fruiting plants. Extraction of important food items of Sloth such as Aegle marmelos, Ficus sp., Ziziphus sp., and honey could threaten the bear, therefore such practice should control.

\section{ACKNOWLEDGEMENTS}

We are grateful to CNP for financial support and DNPWC for providing research permission. Our special gratitude to Dr. Jhamak Karki, then Chief Conservation Officer and other staff of CNP, staff of Biodiversity Conservation, National Trust for Nature Conservation for their support and cooperation during field work. Mr. Dinesh Ghimire deserve special thanks his support and help.

\section{REFERENCES}

Bargali, H.S., Akhtar, N. and Chauhan, N.P.S. 2004. Feeding ecology of Sloth bears in a disturbed area in Central India. Ursus 15 (2): 212-217

Bargali, H.S., Akhtar, N. and Chauhan, N.P.S. 2012. The Sloth bear activity and movement in highly fragmented and disturbed habitat in Central India. World Journal of Zoology 7(4): 312-319

Baskaran, N., Sivaganesan, N. and Krishnamoorthy, J. 1997. Food habits of Sloth bear in Mudumalai Wildlife Sancturary, Tamil Nadu, Southern India. Journal of the Bombay Natural History Society 94 : $1-9$

Garshelis, D.L., Joshi, A.R., Smith, J.L.D, and Rice, C.G. 1999. Sloth Bears Conservation Action Plan. In Serven, C. and Peyton, B. Eds., Bears: Status survey and conservation action plan IUCN/SSC bear and Polar bear Specialist Groups. IUCN, Gland, Switzerland. 225-240

Gokula, V., Sivaganesan, N. and Varadarajan, M. 1995. Food of Sloth bear (Melursus ursinus) in Mundanthurai Plateau, Tamil Nadu. Journal of Bombay Natural History Society 92:408-410

Joshi, A.R., Garshelis, D.L. and Smith J.L.D. 1995. Home range of Sloth bear in Nepal. Implication for conservation. The Journal of Wildlife Management 59(2): 204-214
Joshi, A.R., Garshelis, D.L. and Smith, J.L.D. 1997. Seasonal and habitat-related diets of Sloth bear in Nepal. Journal of Mammology 78: 584-597

Laurie, A. and Seidensticker, J. 1997. Behavioural ecology of the Sloth bear. Journal of Zoology 182(2): 187-204

Machutchon, A.G. and Wellwood, D.W. 2003. Grizzly bear food habits in the Northern Yukon, Canada. Ursus 14: 225-235

Mewada, T. and Dharaiya, N. 2010. Seasonal dietary composition of Sloth bear (Melursus ursinus) in the reserve forest of Vijayanagar, North Gujarat, India. Tiger paper 37(2): 8-13

R Development Core Team. 2013. R: A Language and Environment for Statistical computing version 2.15.2. R Foundation for Statistical Computing, Viena, Austria. http://www.R-project.org. Accessed on 13 June, 2013.

Ramakrishnan, B. and Deepalakshmi, S. 2012. Food habits of Sloth Bear (Melursus ursinus) in the upper Nilgiri Plateau Western Ghats. Tamil Nandu, India. (Abs) $21^{\text {st }}$ International conference on Bear Research and Management. Nov 26-30: 234

Sajer, K.V. 2012. Ecology and feeding behaviour of Sloth Bear (Melursus ursinus) in Parambikulam Tiger Reserve, Kerela. (Abs) $21^{\text {st }}$ International conference an Bear Research and Management Nov 26-30 : 206

Shrestha, K. K. 1993. Food habit analysis of Sloth Bear (Melursus ursinus) in Royal Chitwan National Park, Nepal. M.Sc. Thesis. Central Department of Zoology, Tribhuvan University, Kathmandu, Nepal.

Sreekumar, P.G. and Balakrishnan, M. 2002. Seed dispersal by the Sloth Bear (Melursus ursinus) in south India. Biotropica 34(3): 474-477

Sukhadiya, D., Gondaliya, H., Joshi, J.V. and Dharaiya, N. (2012). Feeding ecology of Sloth bear in Jassore Wildlife Sanctuary with special reference to seasonal variation in diet composition. (Abs) $21^{\text {st }}$ International Conference an bear Research and Management Nov 26-30: 207

Yoganand, K., Rice, C.G.and Johnsingh, A. J. T. 2005. Annual technical report of the project "Evaluating Panna National Park with special reference to ecology of Sloth bear (Melursus Ursinus). Wildlife institute of India, Dehradun, India. 